\title{
STUDIES OF THE POTATO MICROSTRUCTURE DURING BLANCHING
}

\author{
P. BONTOVICS ${ }^{\mathrm{a}}$ and A. SEBŐK \\ Campden \& Chorleywood Food Industry Development Institute Hungary, \\ H-1094 Budapest, Márton u. 3/b. Hungary
}

(Received: 27 November 1998; accepted: 16 March 1999)

\begin{abstract}
The texture changes of potatoes (variety Desire) at different blanching times (0-240 s) and temperatures $\left(85^{\circ} \mathrm{C}, 95^{\circ} \mathrm{C}, 100^{\circ} \mathrm{C}\right)$ were examined within this study.

After blanching the breaking forces $(\mathrm{N})$ were determined with an INSTRON texture analyser (type 1140). The logarithm of the breaking force as a function of blanching time show that 3 different stages $(0-40 \mathrm{~s} ; 40-160 \mathrm{~s} ; 160-240 \mathrm{~s})$ were found at all temperatures $\left(85^{\circ} \mathrm{C}\right.$, $95^{\circ} \mathrm{C}, 100^{\circ} \mathrm{C}$ ).

Photographs of potato cells were taken from scanning electron microscopy studies. Results show that the swelling and gelatinization of the potato starch has only little influence on the texture during the first $(0-40 \mathrm{~s})$ of the 3 different observed stages. In this initial stage the breaking forces increased with time.

The water uptake of the potato cells was determined gravimetrically. The results show that the increase of the breaking forces during the first $40 \mathrm{~s}$ results from the water uptake.

The examinations with the scanning electron microscopy and the texture analyser proved that the main reason for the changes in texture are due to softening and destruction of the cell walls. In the second (40-160 s) and third stage (160-240s) of the blanching process a linear relationship was found between the logarithm of the breaking force and the blanching time.
\end{abstract}

Keywords: potato, blanching, texture, microstructure

The aim of blanching. Due to different activity losses of the enzymes with decreasing temperature, changes in colour, scent taste and aroma composition occur even at freezing temperatures. A minimum temperature for enzymatic reactions cannot be given. Activities for catalase and peroxidase were found at a temperature of $-15^{\circ} \mathrm{C}$, for lipase and lipoxidase at $-30{ }^{\circ} \mathrm{C}$, and for invertase at $-40{ }^{\circ} \mathrm{C}$.

Most vegetables must be blanched before freezing to inactivate enzymes. Beside the inactivation at low energy consumption the blanching prevents the leaching of nutritive and effective substances. Air which is trapped within the cells is removed.

a Present address: SOLVENT Kereskedóház Rt, 1097 Budapest, Gubacsi út 25-29. Hungary 
During blanching not only enzyme catalysed reactions are prevented but also the texture of vegetables changes. These textural changes can be measured by different test procedures. Among these are also analytical methods (HARADA \& PAULUS, 1986). The most common methods are scanning electron microscopy and mechanical tests.

Many papers can be found that describe the textural changes. But by reviewing them it is not possible to associate the softening of the cell wall with only a few effecting factors. We separated the factors as product and process related.

Product related factors. Following WARREN and co-workers (1975) it is difficult to evaluate the influence of a single factor without looking at others. One of the most important factors that influences the texture of raw and blanched potatoes is the chemical composition (BOURTON, 1989; LiNEHAN \& HUGHeS, 1969; WARREN \& WOODMAN, 1973).

Starch: Much attention is paid to the relationship between starch content and texture. Still it is not possible to identify the role of the starch exactly.

MICA (1985) concludes that potato starch has not got a dominant influence upon the texture although potatoes with a high starch content have a firmer structure than those with a low starch content. It is shown that the texture is influenced rather by the physical properties of the starch than by its content.

REEVE (1977) describes cell separation by cell expansion as an important factor for the softening of cell tissues by computing microscopic photographs. During the gelatinization of the starch the volume of each starch granule increases. The volume increase builds up a pressure directed to the cells walls. This pressure is named swelling power (HAYDAR et al., 1980).

Whereas VOISEY (1976) infers from microscopic photographs of blanched potato cells that the influence of starch on the cell damage found is neglectable.

Process related factors. Following REEVE (1977) the softening of cell tissues is influenced by the processing of different potato species. NONAKA (1980) associate the changes with different blanching processes.

Structural changes during blanching: The softening of the cell tissues and therefore the textural changes can be quantified by determining the breaking or shearing force as a function of blanching time.

PAULUS and SAGUY (1980) found a logarithmic relationship between objective textural parameters and the blanching time at constant temperature. In a series of studies the entire range of blanching $(0-15 \mathrm{~min})$ was examined with larger time intervals between the single data points.

HARADA and co-workers (1985) used shearing force measurement to determine the cooking kinetics of different potato species (Bintje, Mentor, Desire) with different blanching temperatures $\left(90^{\circ} \mathrm{C}, 100^{\circ} \mathrm{C}, 110^{\circ} \mathrm{C}\right)$. The measurements helped to predict the cooking behaviour of different species. 
VERLINDEN and co-workers (1995) developed a model which describes the textural changes of potatoes with first order reaction kinetics.

Results presented by BOURNE (1987) indicate that the softening of vegetable tissues (carrots, green beans) can also be described with first order reaction kinetics, but with different slopes for two different phases.

The structural changes during the first 4 minutes have so far not been studied, although this time interval plays the most important role for the blanching of vegetables in the frozen food industry. It was the aim of the study presented here to examine this initial period of the blanching process.

\section{Material and methods}

For the study fresh potatoes (variety Desire; storage $10^{\circ} \mathrm{C}$ ) from the regular supply of the Hungarian frozen food industry as test samples were used with a starch content of 14 to $17 \%$, the dry substance 22 to $24 \mathrm{~g} / 100 \mathrm{~g}$. Cylindrical specimens (diameter: $25 \mathrm{~mm}$; height: $14 \mathrm{~mm}$ ) were cut from potatoes.

Samples (15 parallel) were blanched in a temperature regulated laboratory water bath $(5 \mathrm{l})$ at different bath temperatures $\left(85^{\circ} \mathrm{C}, 95^{\circ} \mathrm{C}, 100^{\circ} \mathrm{C}\right)$ and different time intervals between 5 to $240 \mathrm{~s}$ and cooled in the air flow at $20^{\circ} \mathrm{C}$.

After blanching the breaking forces of 15 samples were determined at $25{ }^{\circ} \mathrm{C}$ using INSTRON texture analyser (Type 1140) with a cylindrical probe (diameter: $57 \mathrm{~mm}$ ) and a crosshead speed of $200 \mathrm{~mm} \mathrm{~min}^{-1}$. For the breaking force the first peak on the forcedeformation curve was used. For the better understanding of the results samples of the raw potatoes were also measured.

Changes in the microstructure were additionally examined with a scanning electron microscope (TESLA BS 300$)$. For the sample preparation potato pieces $(3 \times 5 \times$ $5 \mathrm{~mm}$ ) were taken from the same position at different potatoes and fixed in a glutaraldehyd solution (5\%) for $2 \mathrm{~h}$. After that the fixing liquid was removed by washing the samples three times with a phosphate buffer solution $(\mathrm{pH} 7.2)$.

In a second fixing step an osmium-tetraoxid solution (1\%) was used during a $1.5 \mathrm{~h}$ period followed by washing with the buffer solution as described before.

In a last step the potato samples were dehydrated with acetone and dried to the critical point with liquid carbon dioxide in BALZERS CPD 020.

A gold layer of $30 \mathrm{~nm}$ was sputtered on the dry potato samples using a cathodic sputter (BALZER SCD 040).

The starch molecules were removed during the samples preparation. The surface of the samples was cut away later in order to show the starch particles.

The water uptake (all measured data contain 15 samples analyses) of the potato cells was determined gravimetrically. 


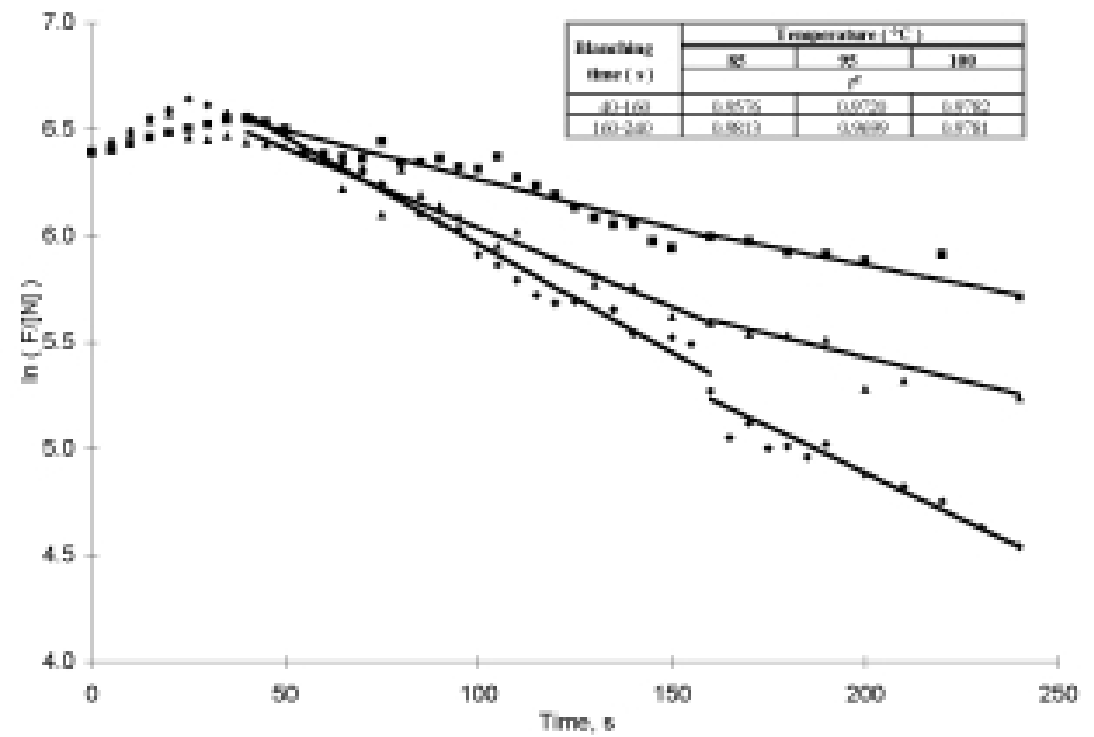

Fig. 1. Changes of the breaking force (ln F) of potatoes during blanching. $\mathbf{\square}: 85^{\circ} \mathrm{C} ; \mathbf{\Delta}: 95^{\circ} \mathrm{C}$;

\section{Results}

The changes in breaking forces for blanched potatoes were examined with the texture analyzer. A transient stage, which lasted for the first 40 seconds, was found at all temperatures $\left(85^{\circ} \mathrm{C}, 95^{\circ} \mathrm{C}, 100^{\circ} \mathrm{C}\right)$. During this transient stage the breaking forces increase as a function of blanching time (Fig. 1). After this initial phase two phases with different slopes were found for the examined blanching temperatures. The relationship between the logarithm of breaking forces and blanching times follows first order kinetics. The coefficients were determined using non-linear regression analysis (Jandel Scientific, Table Curve 2D for Windows). Correlation coefficient $\mathrm{r}^{2}$ are plotted in Fig. 1 for the different phases.

A slight vaulting of the otherwise straight cell wall level was also found by REEVE (1977). He relates the vaulting to gelatinization of the starch.

The following results of the study presented here show that the increase of the breaking forces is not due to the gelatinization but to the water uptake of the potato cells. 


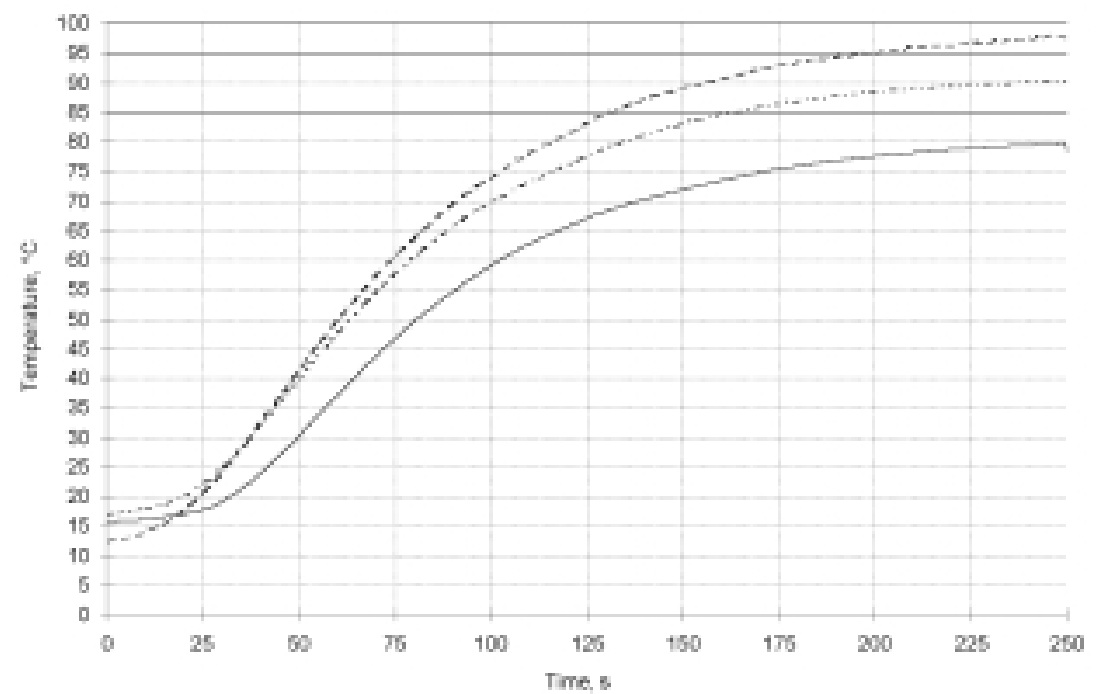

Fig. 2. Core temperature of a potato sample during blanching at $-85^{\circ} \mathrm{C}$; $-\quad-95^{\circ} \mathrm{C}$; and $-100^{\circ} \mathrm{C}, 0-250 \mathrm{~s}$

The core temperature of the potato samples was measured during blanching at $85{ }^{\circ} \mathrm{C}, 95{ }^{\circ} \mathrm{C}$ and $100{ }^{\circ} \mathrm{C}$. The results are presented in Fig. 2. As Fig. 2 shows the maximum core temperature at $100^{\circ} \mathrm{C}$ blanching temperature at $40 \mathrm{~s}$ reaching not more than $35^{\circ} \mathrm{C}$. Following PRAVISANI and co-workers (1985) even a temperature of $67.5^{\circ} \mathrm{C}$ is not sufficient for the gelatinization of starch.

The examinations with the scanning electron microscopy support the statement that the increase of the breaking forces during the first $40 \mathrm{~s}$ is resulting from the water uptake.

Figure 3 shows that the potato cells take up water. As a results the intracellular pressure increases and the cells vault. Figure 4 shows the difference between raw potato cells (Fig. 4a) and vaulted potato cells (Fig. 4d). Only a small number of starch particles can be seen on the photographs (Fig. 4). Some of the starch molecules were removed during the sample preparation. 


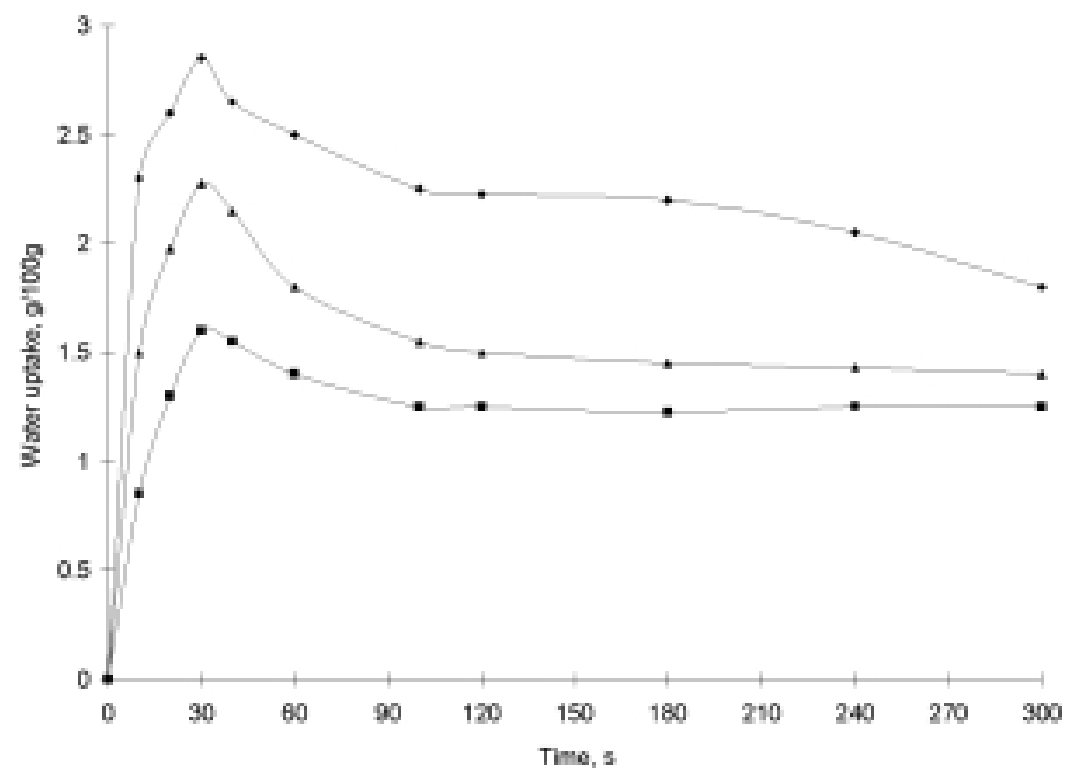

Fig. 3. Water uptake of potatoes during blanching. $\square: 85^{\circ} \mathrm{C} ; 95^{\circ} \mathrm{C} ;: 100{ }^{\circ} \mathrm{C}, 0-300 \mathrm{~s}$

The surface of the samples was cut away later in order to show the starch particles (Figs 5 and 6.). This lead to the destruction of the cell walls. With the latter samples, examples are presented in Fig. 5, it is possible to prove that the starch remained intact within the cells even after $30 \mathrm{~s}$ of blanching. Therefore it can be stated that starch does not play an important role during this initial phase of blanching.

During the first linear phase between $40-160 \mathrm{~s}$ the starch has only limited influence upon the textural changes of potatoes.

When samples are compared after $120 \mathrm{~s}$ which were blanched at $95{ }^{\circ} \mathrm{C}$ and $100{ }^{\circ} \mathrm{C}$ (Fig. 6) it can be shown that at $95{ }^{\circ} \mathrm{C}$ not more than $50 \%$ of the starch gelatinized while at $100^{\circ} \mathrm{C}$ nearly all of the starch gelatinized. As no statistically significant differences in the breaking force could be measured it becomes clear that the differences are not related to the starch. The decrease of the breaking forces in this phase can be explained with the softening of the potato cell tissues.

Changes in the texture which are related to the shrinking of the cell walls and to the softening of cell tissues are presented in Fig. 4f, g. 

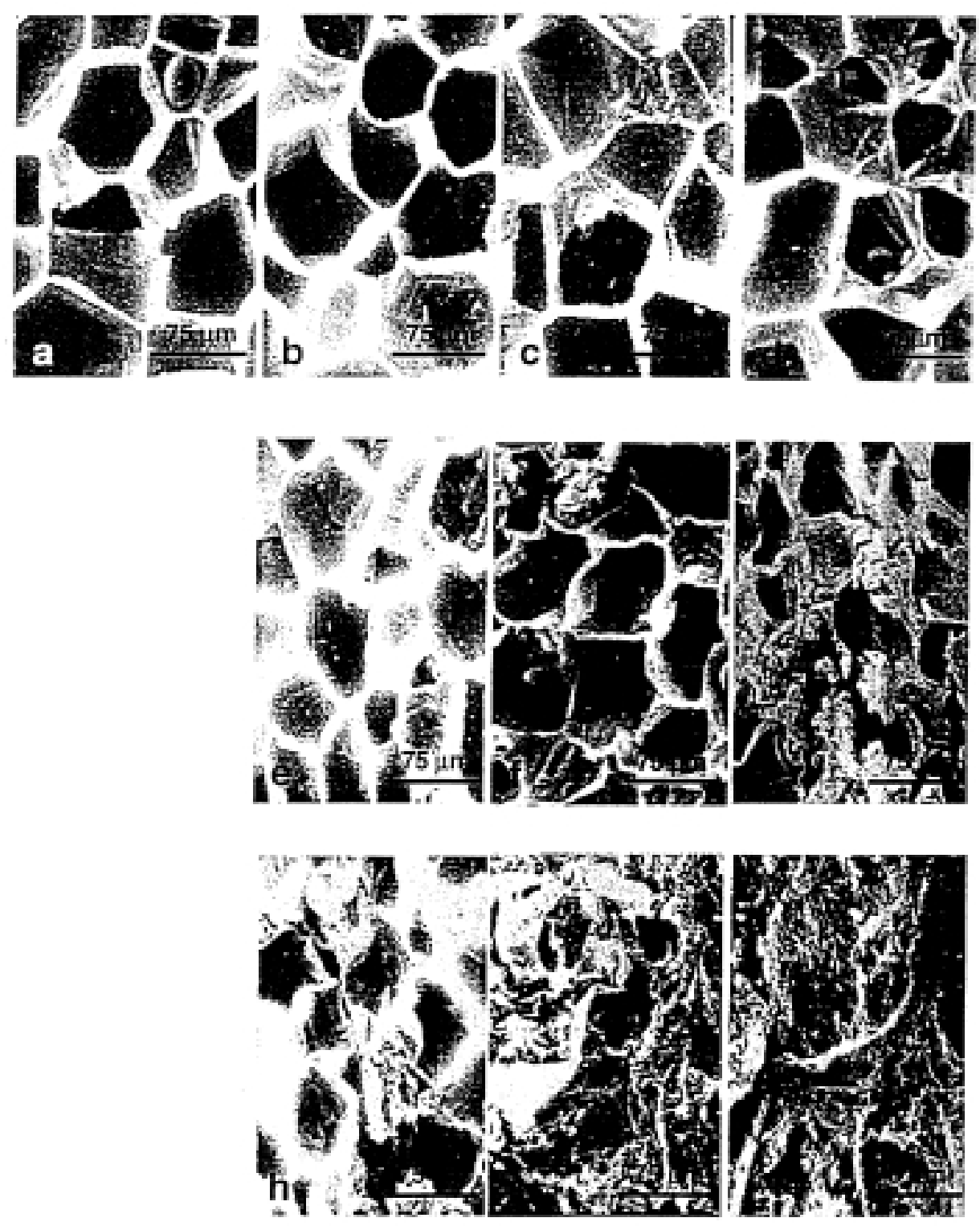

Fig. 4. Ultrastructure (SEM) of the heat-treated (in water) potatoes tissue. (Some of the starch molecules were removed during the sample preparation.)

a: raw; b: $85^{\circ} \mathrm{C}, 30 \mathrm{~s} ; \mathrm{c}: 95^{\circ} \mathrm{C}, 30 \mathrm{~s} ; \mathrm{d}: 100^{\circ} \mathrm{C}, 30 \mathrm{~s}$; e: $85^{\circ} \mathrm{C}, 120 \mathrm{~s} ; \mathrm{f}: 95^{\circ} \mathrm{C}, 120 \mathrm{~s} ; \mathrm{g}: 100^{\circ} \mathrm{C}, 120 \mathrm{~s}$; h: $85{ }^{\circ} \mathrm{C}, 240 \mathrm{~s} ;$ i: $95{ }^{\circ} \mathrm{C}, 240 \mathrm{~s} ;$ j: $100{ }^{\circ} \mathrm{C}, 180 \mathrm{~s}$ 

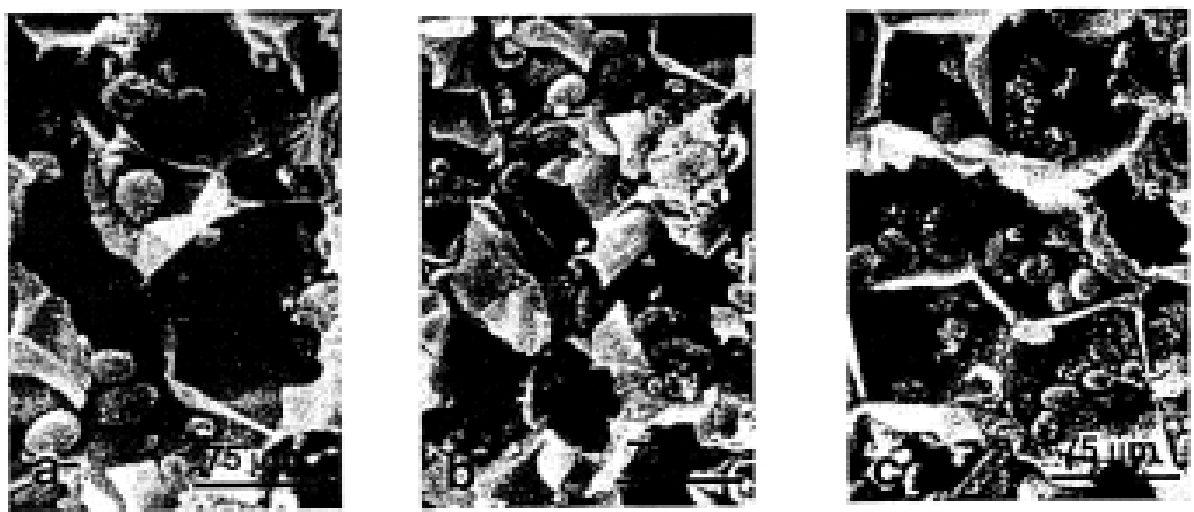

Fig. 5. Ultrastructure of starch particles in potato cells during blanching at different temperatures. (The surface of the samples was cut.) a: $85^{\circ} \mathrm{C}, 30 \mathrm{~s} ; \mathrm{b}: 95^{\circ} \mathrm{C}, 30 \mathrm{~s} ; \mathrm{c}: 100^{\circ} \mathrm{C}, 30 \mathrm{~s}$
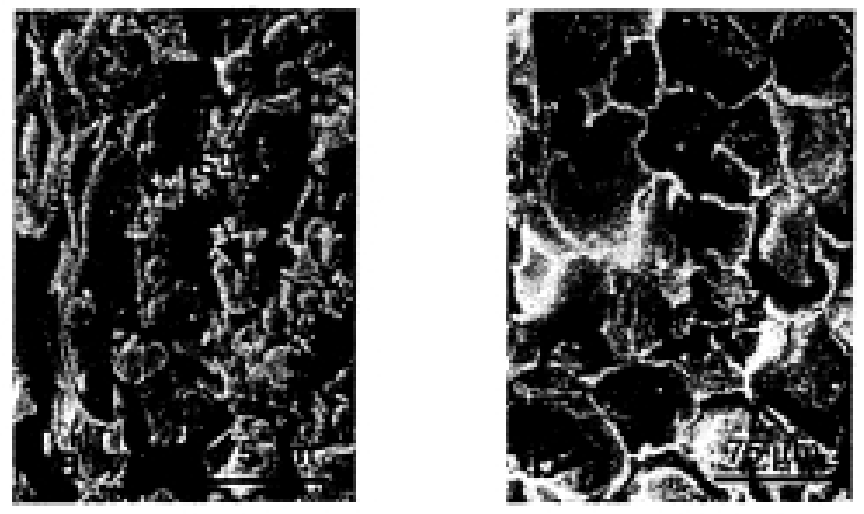

Fig. 6. Amount of gelatinization of starch particles in potato cells at different temperatures. (The surface of the samples was cut.) a: $95^{\circ} \mathrm{C}, 120 \mathrm{~s} ;$ b: $100{ }^{\circ} \mathrm{C}, 120 \mathrm{~s}$; S: starch particles

From the results presented so far it can be concluded that potato starch does not play a dominant role during the first two phases of blanching $(0-160 \mathrm{~s})$ at the examined temperatures. The entire cell wall structure is destroyed at $100{ }^{\circ} \mathrm{C}$ between a blanching time of 120 and $180 \mathrm{~s}$. An amorphous matrix substance is shown in Fig. 4j. A very similar cell structure is obtained after blanching at $95{ }^{\circ} \mathrm{C}$ for $240 \mathrm{~s}$ (Fig. 4i). Also the 
breaking forces were similar (Fig. 1) for those blanching conditions. Opposite to this the texture change is much slower at $85^{\circ} \mathrm{C}$ (Fig. 4h). This slower change can be explained with the activity of the enzyme pectinmethylesterase and the protein denaturation (LIU et al., 1993).

On Fig. $4 \mathrm{~b}$, e thickenings in the cell walls can be seen which are due to the denaturation of proteins.

During the last phase (160 to $240 \mathrm{~s}$ ) it cannot be excluded that the gelatinization of the starch plays an important role which leads to the amorphous structure at $95^{\circ} \mathrm{C}$ and $100{ }^{\circ} \mathrm{C}$.

Finally, it can be concluded that under none of the examined blanching temperatures the potato starch is the dominant factor for changes of the texture between 0 and $240 \mathrm{~s}$.

\section{Discussion}

The objectives of this research work were to study structural changes in potatoes during blanching of different time intervals $(0-240 \mathrm{~s})$ at different temperatures $\left(85^{\circ} \mathrm{C}\right.$, $95^{\circ} \mathrm{C}, 100^{\circ} \mathrm{C}$ ) and to explain the causes of changes found.

The influence of starch upon the structural changes as one of the possible causes was discussed. It could be shown that starch neither plays a dominant role during the transient initial phase $(0-40 \mathrm{~s})$ nor during the following phase where a linear correlation exists between the logarithm of the breaking force and the blanching time (40-160 s). During the last observed phase (160-240 s) the influence cannot be entirely excluded. Again, a linear relationship between the logarithm of breaking force and time is found but with a different slope. An increase in the breaking force at the beginning of the blanching can be explained with the water uptake. In the linear phases a decrease of the breaking forces can be observed which is related to the shrinking of the cell walls and the softening of the cell tissues.

It could be shown in this study that the observed changes are temperature dependent and are slower at lower temperatures. If the temperature dependent change of breaking forces is known, blanching processes can be optimised with respect to product quality. 


\section{References}

BOURNE, M. C. (1987): Effect of blanch temperature on kinetics of thermal softening of carrots and green beans. J. Fd Sci., 52, 667-668, 690.

BOURTON, W. G. (1989) Cooking and processing quality -in: BOURTON, W. G. (Ed.) The potato. 3rd ed., Longman Scientific and Technical, Harlow, pp. 391-422.

HARADA, T \& PAULUS, K. (1986): Analytical method to characterise the cooking behaviour of potatoes. Lebensm. Wiss. Technol., 19, 39-43.

HARADA, T., TIRTOHUSODO, H. \& PAULUS, K. (1985): Influence of temperature and time on cooking kinetics of potatoes. J. Fd Sci., 50, 459-462, 472.

HAYDAR, M., MOLEDINA, K. H., OORAIKUL, B. \& HADZIYEV, D. (1980): Effect of calcium and magnesium on cell wall and starch of dehydrated potato granules. J. agric Fd Chem., 28, 383-391.

LINEHAN, V. J. \& HUGHES, J. C. (1969): Texture of cooked potato. J. Sci. Fd Agric., 20, 110.

LIU, K., HUNG, Y. C. \& PHILLIPS, R. D. (1993): Mechanism of hard to cook defect in cowpeas: verification via microstructure examination. Fd Struct., 12, 51-58.

MICA, B. (1985): Einfluss der Stärke auf die Textureigenschaften von Kartoffelknollen. Stärke, 35, 407-410.

NONAKA, M. (1980): The textural quality of cooked potatoes. I. The relationship of cooking time to the separation and rupture of potato cells. Am. Potato J., 57, 141-149.

PAULUS, K. \& SAGUY, I. (1980): Effect of heat treatment on the quality of cooked carrots. J. Fd Sci., 45, 239-241, 245.

Pravisani, C. J., CALIfANO, A. N. \& CALVAlO, A. (1985): Kinetics of starch gelatinization in potato. J. Fd Sci., 50, 657-660.

REEVE, R. M. (1977): Pectin, starch and texture of potatoes: some practical and theoretical implications. $J$. Texture Studies, 8, 1-17.

VERLINDEN, B. E., NiCOlAI, B. M. \& BAERDEMAEKER, J. (1995): The starch gelatinization in potatoes during cooking in relation to the modelling of texture kinetics. J. Fd Engng., 24, 165-179.

VOISEY, P. W. (1976): Microstructure of food and its relation to texture. -in: DEMAN, J. M., VOISEY, P. W., RASPER, V. F. \& STANLEY, D. W. (Eds) Rheology and texture in food quality, AVI Publ. Co., Westport, pp. 35-75.

WARREN, S. D., GRAY, D. \& WOODMAN, J. S. (1975): Relationship between chemical composition and breakdown in cooked potato tissue. J. Sci. Fd Agric., 26, 1689-1697.

WARREN, S. D. \& WOODMAN, J. S. (1973): Distribution of cell wall components in potato tubers: A new titrimetric procedure for the estimation of total polyuronide (pectin substances) and its degree of esterification. J. Sci. Fd Agric., 24, 769-777. 